\title{
Žákovské portfolio - vhodná forma hodnocení environmentální výchovy
}

\section{Kateřina Jančaříková}

Envigogika 2007/II/3 - Recenzované články/ Reviewed Papers

Publikováno/Published 30. 12. 2007

DOI: http://dx.doi.org/10.14712/18023061.23

\section{Abstrakt:}

Cílem tohoto článku je propagovat portfoliové hodnocení pro evaluaci průřezového tématu environmentální výchova.

\section{Klíčová slova:}

$\operatorname{xxxx}$

\section{Abstract:}

The aim of this article is to promote the use of a portfolio as an evaluation tool for the cross-cutting theme of environmental education in curricula. This instrument represents an alternative form of evaluation in pedagogical praxis - and it offers a simple, effective and unbiased tool, compared with examination and testing. On the other hand, in the Czech Republic it is often understood as a collection of marked tests over a long time period. For this reason, a recommendation from the SKAV roundtable suggested using the term "student's portfolio".

\section{Key words:}

$x x x x$ 


\section{Představení evaluace na základě portfolia}

\section{Portfolio v pedagogice}

Portfolio je podle oxfordského slovníku současné angličtiny „plochá krabice k uchování volných papírů, dokumentů, výkresů atd." Ve vzdělávání může mít různé podoby (nejčastěji krabice nebo pořadač, desky s výkresy, ale také $C D$ nosič nebo videokazeta). Student i žák (zpočátku za asistence učitele, rodičů, sourozenců nebo kamarádů) do portfolia zakládá reprezentativní vzorek svých prací.

Cílem zavedení portfolia do pedagogické praxe bylo vytvořit alternativu k hodnocení na základě psaných testů nebo zkoušení ze znalostí. Portfolio nabízí jednoduchou, velice efektivní a k inteligencím spravedlivou metodu hodnocení studentské a žákovské práce a konec znalostních testů ${ }^{1}$ (Gardner, 1993). Hodnocení na základě portfolia umožňuje sledovat celoroční práci, eliminuje zkreslení výsledku hodnocení vlivem krátkodobé indispozice (trémy, menstruace dívek, počínající virózy), které se $v$ písemném testu i v ústním zkoušení negativně projevuje.

Přesto, že je metoda hodnocení na základě portfolia v zahraničí poměrně často citována (např. Flood \& Lapp, 1989; Hiebert \& Calfee, 1989; Jongsma, 1989; Katz, 1988; Rothman, 1988; Shepard, 1989; Valencia, 1990a; Valencia, 1990b; Wiggins, 1989a; Wolf, 1989 - přehled citací z Moya; O'Malley, 1994) a v na některých místech se v USA (např. California Assessment Program) stala i součástí vzdělávací reformy, není v České republice stále dostatečně využívaná.

Navzdory tomu je již v České republice možné se setkat s pedagogy, kteři pod slovem "portfolio", zcela v rozporu s původním záměrem, rozumí složku obsahující oznámkované písemky a testy za celou dosavadní dobu žákovy školní docházky. Na kulatém stolu SKAV (květen 2006) bylo proto toto počínající rozmělnění termínu portfolio diskutováno a bylo doporučeno pro zdůraznění původního pedagogického záměru používat pojem „žákovské resp. studentské portfolio" (Hrubá, 2006).

\section{Obsah a typy žákovského portfolia}

Obsah portfolia je velmi individuální, vždyt', jak bylo uvedeno v předchozím odstavci, závisí na iniciativě žáka samotného. Výtvarně nadaný žák bude mít v portfoliu více kreseb, literárně nadaný žák více esejů, a podobně. Obvykle portfolio obsahuje: pracovní listy, fotografie, kresby, zápisy z pozorování, mapy, př́rodniny, deník z výletů, komentáře pedagoga, oborníků nebo spolužáků k dané problematice apod. účelové.

Hlavní typy portfolia jsou: dokumentační, tematické, pracovní (process portfolio),

Dokumentační portfolio obsahuje veškerou činnost související s danou problematikou $v$ nějakém časovém úseku (je vázáno např. na jedno pololetí, na jeden

1 V kontextu situace $v$ USA se jedná o celostátní Scholastic Aptitude Test. Tyto testy reprezentují tzv. hamiltonovskou tradici amerického školství, která na amerických školách zavedla testování IQ. Gardner, Sternberg a další odborníci poukázali na skutečnost, že někteří vynikající vědci a spisovatelé v mládí v SAT testu neuspěli a že vzhledem $k$ tomu, že je výsledek v SAT testu chápán jako důležité kritérium pro přijetí na vysokou školu, je možné, že se společnost jejich používáním připravuje o potencionální talenty. Gardnerovi se u přijímacích pohovorů (nejprve na Bates College, Franklin a Marschall College a následně $v$ rámci kurikulární reformy $v$ celé Kalifornii) podařilo iniciovat nahrazování SAT testů portfoliovým hodnocením. 
školní rok, na první stupeň ZŠ), při jeho prohlížení vidí hodnotící osoba studentovo resp. žákovo zlepšování, jeho posun od laické k profesionální úrovni.

Tematické portfolio ${ }^{2}$ je vytvořeno podle např. předmětů (matematické portfolio) nebo zacílené na konkrétné interdisciplinární projekt např. Voda a život, Výprava k moři, Semická hưrka, Včely, Pozorování kosího hnízda, apod.

Pracovní portfolio ${ }^{3}$ je kombinací obou předchozích typů, zachycuje totiž nejen výsledek nějaké činnosti, ale i činnost samu, proces, práci na konkrétním projektu, včetně nezrealizovaných nápadů, vedlejších uliček, neúspěchů. Takové portfolio obsahuje hrubé náčrty projektu (obvykle $v$ několika verzích), studentovy korekce, výsledný produkt a připomínky různých odborníků nebo i spolužáků $\mathrm{k}$ němu, reflexe uživatelů projektu (čtenářu, návštěvníků výstavy). Proces práce na určitém projektu může být dokumentován i vizuálně - videokamerou ${ }^{4}$.

Účelové portfolio (podle Strakové prezentační portfolio) je vytvořené za konkrétním účelem prezentace studentských resp. žákovských schopností. Do účelového portfolia se vybírají nejlepší práce $v$ dané oblasti, tak aby bylo možné předvést studentovy kvality a schopnosti např. u přijímacích zkoušek (na UK-PedF, katedře biologie a ekologické výchovy je tato forma možná ji několik let), nebo u státních závěrečných zkoušek (na UK-PedF je možné skládat státní zkoušku z primární pedagogiky na základě pohovoru nad portfoliem), nebo při vstupním pohovou do zaměstnání i jiných příležitostech (na krajských kolech soutěže Zelená stezka-Zlatý list je podmínkou doložit portfoliem celoroční soutěžících skupin pro prírodu a $v$ prírodě).

\section{Portfoliové hodnocení v České republice}

Portfolia (pod jiným, neustáleným názvem např. soubor, složka, dokumentace) byla a jsou u nás tradiční součástí přijímacích pohovorů a závěrečných zkoušek na všech typech výtvarných škol pro hodnocení výtvarných prací žáků a studentů při přijímacích a závěrečných zkouškách, na školách technických (architektura, strojírenství) se ke zkouškám obdobně přináśí desky s výkresy, deskriptivními rysy, apod. jejich využití má tradici také $v$ některých mimoškolních aktivitách např. $v$ prrírodovědných kroužcích.

Poprvé $v$ historii bylo portfoliové hodnocení všech předmětů žáků prvního stupně použito v roce 1998 jako nástroj evaluace experimentu "domácí vzdělávání" na ZCŠ Bratrské škole v Praze, později i na ZŠ Vrané nad VItavou a ZCŠ Ostrovní v Praze a dalších (Jančař́ková, 2007).

O něco později začalo být portfoliové hodnocení používáno také pro hodnocení žáků základních škol mimo individuální vzdělávání, tj. vzdělávaných klasicky, na některých progresivních školách (ZŠ Chlupova v Praze, ZŠ a MŠ Košetice, ZŠ Prachatice aj.).

A také na některých progresivních, obvykle pedagogicky zaměřených, školách vysokých (např. na některých katedrách UK PedF).

\footnotetext{
${ }^{2}$ Gardner používá pojem student's project or project portfolio.

${ }^{3}$ Gardner ho nazývá processportfolio.

${ }^{4}$ Gardner pak hovoří o videoportfoliu.
} 


\section{Hodnocení environmentální výchovy a nástroje hodnocení environmentální výchovy}

Hodnocení environmentální výchovy

Výraz "hodnocení environmentální výchovy" v sobě skrývá

1. nástroje hodnocení žáků/studentů, které používá učitel

2. způsoby hodnocení, klasifikace žáků/studentů učitelem (průběžná a závěrečná)

3. hodnocení kvality a účinnosti environmentální výchovy (evaluaci a autoevaluace vyučujícího nebo školy)

\section{Nástroje hodnocení environmentální výchovy používané v zahraničí}

Nástroje hodnocení environmentální výchovy využívané v zahraničí (Palmer, Neal, 1994 a Wilke, 1993):
1. ústní zkoušky,
2. písemné testy,
3. eseje,
4. výzkumné projekty,
5. vědecké experimenty,
6. debaty a filosofické disputace,
7. umělecké výstupy (výstava, film),
8. písemné hodnocení,
9. studentské portfolio.

Hodnocení environmentální výchovy, zvláště alternativnímu, není podle zahraniční hyperstudie (Wilke, 1993 str. 152 nn) věnována dostatečná pozornost.

\section{Problematika hodnocení průřezového tématu environmentální výchova v ČR - výzkumná sonda}

Od 1. 9. 2007 je poprvé v historii našeho státu environmentální výchova ze zákona povinná, a to minimálně ve všech 1 . a 6 . tř́ldách. A poprvé byla nebo alespoň mohla být klasifikována a zapsána na vysvědčení.

RVP ZV ale nedeterminuje ani nástroje ani způsob hodnocení průřezových témat (a tedy ani environmentální výchovy).

Protože dosud nebyl publikován výzkum, který by se zabýval tím, jak učitelé hodnotí resp. budou/chtějí hodnotit environmentální výchovu (resp. všechna prưřezová témata), byla v roce 2007 udělána mezi pedagogy z praxe výzkumná sonda metodou Sběr pojmů. 


\section{Metodika}

Sběr pojmů je jedním z kvalitativních nástrojů metody "Zakotvená teorie" (Strauss, Corbin, 1998). Metoda Sběr pojmů umožnila rychle a přesně vyhledat všechny zpưsoby hodnocení EV, které se $v$ dané skupině vyskytují/využívají. Otázky byly kladeny učitelkám ZŠ (1. i 2. stupně) v rámci postgraduálních kurzů EV a kombinovaného studia UK-PedF. Celkem byla výzkumná sonda provedena $v$ osmi skupinách učitelů z praxe (= 240 osob); došlo k teoretickému nasycení vzorku.

\section{Výsledky a jejich diskuse}

Na otázku o způsobu hodnocení environmentální výchovy byly od pedagogů z praxe takovou malou výzkumnou sondou ${ }^{5}$ zaznamenány tyto odpovědi:

1. učitelé environmentální výchovu vůbec nehodnotí ${ }^{-}$- a nad tím, jak má být hodnocena se ještě nikdy nezamysleli

2. učitelé environmentální výchovu hodnotí slovně/ústně (okamžitá pochvala žáka, ocenění na třídních schůzkách, prostor pro hodnocení v rámci reflexe na konci projektu apod.)

3. učitelé environmentální výchovu hodnotí slovně/písemně v rámci slovního hodnocení na 1 . stupni ZŠ

4. učitelé environmentální výchovu hodnotí jako nepovinný předmět (slovy „pracoval/a úspěšně" na vysvědčení)

5. učitelé hodnotí environmentální výchovu obvyklým zpưsobem klasifikací (škálou 1 - 5) na vysvědčení

Pokud učitelé EV nehodnotí, ani se nad jejím hodnocení nezamýšlí, je velmi pravděpodobné, že environmentální výchova neprobíhá, tak jak by měla. Přes tuto otázku (Jak hodnotíte EV u vás na škole?) by možná stálo za to provést výzkum kvality environmentální výuky a výchovy.

Známkování a testování je zcela v rozporu s cíly, které si environmentální výchova a vzdělávání klade. Pokud učitel zvolí formu klasického známkování, pravděpodobně bude k získání známek používat klasické testy na znalosti. Žáci se budou soustředit na hromadění informací, které potřebují k dosažení úspěšných výsledkù, a na odhadování toho „co asi učitel chce slyšet”. Známkování může při budování environmentální senzitivity hrát kontraproduktivní roli (srov. Franěk, 2000). takto:

Na dotaz ohledně nástrojů hodnocení environmentální výchovy učitelé odpovídají

\footnotetext{
5 Jedná se o metodu Zakotvené teorii - sběr pojmů. Tato metoda nekvantifikuje, jen umožňuje vyhledat všechny pojmy - $v$ tomto př́padě zpưsoby hodnocení $E V$, které se $v$ dané skupině vyskytují/využívají. Otázky byly kladeny učitelkám ZŠ (1. i 2. stupně) v rámci postgraduálních kurzů EV a kombinovaného studia UK-PedF. Celkem v osmi skupinách (240 osob). Došlo k teoretickému nasycení vzorku (= nepřibývaly další pojmy)

${ }^{6}$ Př́tomný čas je použit proto, že část učitelů byla z pilotních škol, na kterých již podle ŠVP vyučují. Většina učitelů pochopitelně odpovídala o tom, jak to za cca čtvrt roku budou realizovat (nebudeme hodnotit, apod.).
} 
1. žádné nástroje nepoužívají, protože environmentální výchovu nehodnotí a hodnotit nebudou

2. k hodnocení environmentální výchovy zadávají písemné testy

3. reflexe - skupinový rozhovor nad projekty

Pokud učitelé EV hodnotí slovně, at' už přiležitostně nebo systematicky ( $v$ rámci vysvědčení), může environmentální výchova probíhat excelentně i nedostatečně - třetí osoba nemá možnost si na kvalitu vyučování EV vytvořit bez dalších vlastní nezávislý názor.

\section{Cíle hodnocení environmentální výchovy}

Základním cílem hodnocení environmentální výchovy na základní škole by mělo být ověřit, zda v prưřezovém tématu environmentální výchova:

1. bylo dítě v př́slušném období vzděláváno

2. došlo k rozvoji jeho dovedností, vědomostí, postojů a hodnot

3. se setkalo s dostatečným množstvím podnětů rozvíjejících environmentální senzitivitu

4. probíraná látka odpovídá kurikulárním dokumentům

\section{Výhody a nevýhody použití portfolia jako nástroje k hodnocení environmentální výchovy}

Portfolio - ideální nástroj hodnocení environmentální výchovy

Žádný jiný způsob hodnocení nezodpoví výše uvedené otázky tak dobře, jako přátelský pohovor nad žákovských portfoliem, při kterém žák společně s dospělým listují portfoliem a povídají si o zápiscích, kresbách, vylisovaných rostlinách, fotografiích, atd. (Wilke, 1993; Palmer, Neal, 1994).

Hodnocení na základě portfolia ${ }^{7}$ je dětem př́jemné. Proto Ize předpokládat, že nebude působit kontraproduktivně na rozvoj environmentální senzitivity.

Žáci se díky tomuto způsobu hodnocení naučí dokumentovat svou práci, protože již při práci samotné uvažují, jak ji zdokumentovat, aby "si ji mohli založit do portfolia". Schopnost dokumentovat svou práci zužitkují v budoucnosti.

Hodnocení na základě portfolia buduje kolektiv - znemožňuje seřazení žáků od nejlepšího po nejhoršího a jejich vzájemného porovnávání. Umožňuje ocenění každého žáka pro jeho osobité a jedinečné schopnosti (jeden umí kreslit, druhý zapisovat, třetí je dobrý pozorovatel, další má skvělé nápady, další tmelí kolektiv) a je tedy základem pro kvalitní týmovou práci.

7 Zkušenosti byly čerpány z experimentu domácího vzdělávání - tj. hodnocení na základě portfolia nejen EV, ale všech předmětů prvního stupně (Jančaříková, 2007). 
Portfoliové hodnocení umožňuje žákovi reflexi: vrátit se k prožitému resp. naučenému (zavzpomínat si, připomenout si, navázat na).

Portfoliové hodnocení poskytuje také platformu pro zlepšení komunikace rodina škola, protože se na jeho tvorbě mohou podílet (a obvykle i podílejí) i rodiče žákù. Do portfolia se totiž mohou (a měly by se) zakládat nejen zážitky prožité se spolužáky, ale také individuální zážitky s rodinou (rodinné výlety, exkurze). A tyto rodinné aktivity, jak dokazuje kvantitativní výzkum (Jančaříková, 2007b), se na rozvoji environmentální senzitivity podílejí v s porovnáním s aktivitami iniciovanými učiteli takřka pětinásobně.

Portfoliové hodnocení také umožňuje třetí osobě získat značný přehled o výuce EV a aktivitách s ní spojených. Takže mưže být nástrojem nejen hodnocení žáka samotného, ale také jeho učitele, rodiny. Tím se ovšem otevírá problematika etická.

\section{Etické aspekty portfoliového hodnocení}

Dítě do portfolia vybírá ze svých výtvorů, portfolio zrcadlí celou jeho osobnost a také atmosféru $v$ rodině, její majetkové poměry, zvyky, náboženské vyznání, vztahy mezi rodiči a sourozenci a další velmi citlivé a intimní informace. To s sebou přináší značná rizika. Při zacházení s portfolii je nezbytné si uvědomit, že by dětská portfolia mohla být zneužita (např. šikana pro jakoukoli neobvyklost, vykradení movité rodiny, únos), kdyby se k portfoliím dostal nepovolaný člověk a učinit nějaká preventivní opatření (přechovávat je v uzamčeném prostoru, respektovat dítě jako vlastníka portfolia).

\section{Časová, prostorová a finanční náročnost portfoliového hodnocení}

Vytváření i vlastní hodnocení portfolia je časově a prostorově náročné. Na začátku je nutné zodpovědět několik otázek: Kdo bude financovat portfolio? Pořizovací náklady na portfolio nejsou velké, ale bude mít škola dost peněz, aby mohla portfolia pořídit všem svým žákům? Nebo budou portfolia financovat rodiče? Budou mít pro tento výdaj dost porozumění? Kdo bude platit náklady spojené s tvorbou portfolia (např. papír, náklady na kopírování, fotografie)? Nebudou děti ze sociálně slabší rodin znevýhodněny např. tím, že jim nebudou rodiče kopírovat do portfolia materiály, fotografie?

Portfolia zabírají prostor. Kde budou portfolia uskladněna? Navíc je nutné, aby byla zajištěna před nepovolanými osobami. Je škola schopna vhodný uzamykatelný prostor pro přechovávání portfolií všech žákủ zajistit?

\section{Závěr}

Portfoliové hodnocení je progresivním nástrojem evaluace. Pro evaluaci environmentální výchovy se jeví minimálně ze dvou důvodů nástrojem ideálním.

Prvním důvodem je samotná podstata portfoliového hodnocení (důraz na respektování různých talentů, důraz na týmovou práci, možnost reflexe, minimalizace negativních vlivů na rozvoj environmentální senzitivity a další výše zmíněné klady).

Druhým důvodem je reálná situace našeho školství - tedy skutečnost, že evaluaci průřezových témat nebyla věnována dostatečná pozornost. Vznikla jakási volná evaluační nika. Vzhledem k pozitivním zkušenostem se domnívám, že by bylo záhodné tuto volnou niku obsadit právě portfoliovým hodnocením.

Téma portfoliové hodnocení environmentální výchovy (a dalších průřezových témat) doporučuji zařadit nejen do pregraduální přípravy učitelư, ale především také do kurzů Specializačního studia pro školní koordinátory EVVO. 


\section{Literatura}

- Franěk, M. . Odcizení prírodě a možnosti environmentální výchovy. Zpravodaj MŽP, 6(2000), 14-15.

- Gardner, H. (1993). Multiple Intelligences : The theory in Practise. New Yourk: Basic Books.

- Učitelské listy . K čemu může sloužit žákovské portfolio?. Učitelské listy, Retrieved from http://www.ucitelske-listy.cz/Ucitelskelisty/Ar.asp?ARI =102653\&CAI=2153

- Jančaříková, K. Portfoliové hodnocení v domácím vzdělávání. In Metodický portál www.rvp.cz : Výběr príspěvků (pp. 120-123). Praha: VúP. Retrieved from http://www.rvp.cz/clanek/3/969

- Jančaříková, K. (2008). Role učitele a rodičů prii realizaci nekognitivních cílů environmentální výchovy žákủ základní školy. In Sborník konference Fórum o premenách školy v 21. storočí. .

- Jančaříková, K., Jančařík, A., Portfolio assessment of elementary pupils. In SEMT '05 International Symposium Elementary Maths Teaching, UK Praha, ISBN (pp. 164-170). .

- Jongsma, K. S. (1989). Portfolio assessment. The Reading Teacher. , 43, 264-265.

- Moya, Ss., , \& O'Malley, JM., (1994). A Portfolio Assessment Model for ESL. The Journal of Educational Issues of Language Minority Students, 13, 13-36. Retrieved from http://www.ncela.gwu.edu/pubs/jeilms/vol13/portfo13.htm

- Palmer, J. (1994). The Handbook of Environmental Education. : London : Routledge.

- Slavík, J. (1999). Hodnocení v současné škole. Praha: Portál.

- Stenberg, R. J. (2001). Úspěšná inteligence : Jak rozvíjet úspěšnou inteligenci. Praha: Grada Publishing.

- Straková, J. . Využití portfolia k hodnocení práce a výsledků žáků - část I. K čemu slouží různé typy portfolií. Moderní vyučování, 9(2005), 6-7.

- Strauss, A. L., \& Corbin, J. M. (1998). Basics of Qualitative Research : Techniques and Procedures for Developing Grounded Theory.London, New delhi : Thousand Oaks. Thousand Oaks: Sage Publications.

- Wilke, R. B. (1993). Environmental education : Teacher Resource Handbook : A practical Guide for K - 12 Environmental Education. Thousand Oaks, California : Corwin press, First Printing. ISBN. Thousand Oaks, Calif: Corwin Press ; c1993. 
Časopis Envigogika vydává Centrum pro otázky životního prostředí UK. Vývoj časopisu je podpořen projektem OP VK Mezioborová sít udržitelného rozvoje.

Více najdete na internetových stránkách projektu mosur.czp.cuni.cz
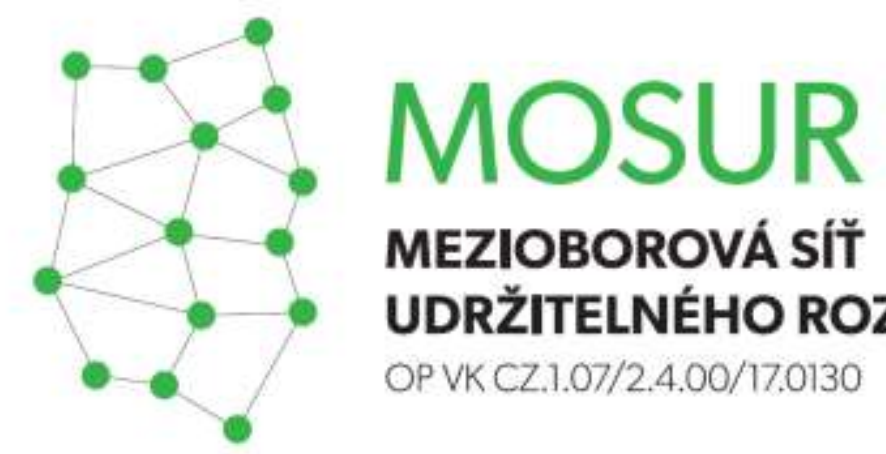

\section{MEZIOBOROVÁ SÍT} UDRŽITELNÉHO ROZVOJE

OP VK CZ.1.07/2.4.00/17.0130
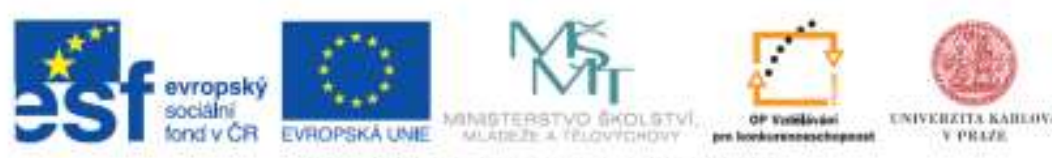

INVESTICE DO ROZVOJE VZDELAVANI 